\title{
Temperature effects on growth and nucleic acids in laboratory-reared larval coregonid fish
}

\author{
A. M. Malzahn ${ }^{1,2, *}$, C. Clemmesen ${ }^{1}$, H. Rosenthal ${ }^{1}$ \\ ${ }^{1}$ Institut für Meereskunde, Düsternbrooker Weg 20, 24105 Kiel, Germany \\ ${ }^{2}$ Present address: Biologische Anstalt Helgoland, AWI, Meeresstation, 27498 Helgoland, Germany
}

\begin{abstract}
Somatic growth and nucleic acid content were studied in North Sea houting Coregonus oxyrhinchus larvae fed exclusively on dry diets at 2 temperatures $\left(8.4\right.$ and $\left.17.5^{\circ} \mathrm{C}\right)$ during a $32 \mathrm{~d}$ rearing experiment. The higher temperature enhanced growth significantly. Mean dry weights at the end of the experiment were $3.6 \mathrm{mg}(\mathrm{SD}=1.07$, range 1.4 to $5.7 \mathrm{mg}$ ) and $31.5 \mathrm{mg}(\mathrm{SD}=21.9$, range 3.6 to $96.0 \mathrm{mg}$ ), and mean standard lengths were $17.7 \pm \mathrm{mm}(\mathrm{SD}=1.6$, range 11.8 to $19.6 \mathrm{~mm})$ and $25.5 \mathrm{~mm}$ $(\mathrm{SD}=4.2$, range 17.0 to $35 \mathrm{~mm}$ ), respectively. Significant responses to temperature were also found in the nucleic acids. However, these differences were not as remarkable and gave indications that differences in protein growth between treatments was based on protein biosynthesis being driven by the activity of the ribosomes, rather than their number. The use of the degree-day approach to normalize the data clearly showed the temperature-dependence of somatic growth. Only small differences in growth and nucleic acid content were observed in the comparable range of the first 280 degree-days in fed fish. In non-fed fish, the starving potential was very similar (approx. 350 degreedays). Shifts in growth pattern from predominantly hyperplasia to predominantly hypertrophy were detected, with ongoing growth at both temperatures.
\end{abstract}

KEY WORDS: Coregonus $\cdot$ RNA:DNA ratio $\cdot$ Temperature effects $\cdot$ Whitefish $\cdot$ Larvae

\section{INTRODUCTION}

One of the major problems to be solved in the field of larval ecology and recruitment studies is the determination of growth rates, or the establishment of measures that can help in predicting the survival potential of larval fish. A fish larvae that survives until metamorphosis has been unusually lucky (Pepin et al. 1999). The major task is to determine the factors influencing the ability to be a survivor. Growth is valid as a predictor of survival, because fast growth may allow the fish to outgrow the dangerous larval period faster, and escape from food-limited areas or predation (Bailey \& Houde 1989, Leggett \& Deblois 1994, Suthers 1998). RNA:DNA ratios are commonly used as indicators for growth rate in marine fish, and have been validated by laboratory and field studies (Buckley 1984, Buckley \& Lough 1987, Clemmesen 1994, Rooker \& Holt 1996, Bergeron 1997, Clemmesen et al. 1997, Gronkjaer et al. 1997, Rooker et al. 1997).
Estimation of recent growth or condition from larval nucleic acid content requires normalisation or adjustment for larval age, development or size (Buckley et al. 1999). The most widely used method has been the normalisation of RNA-content to DNA-content, expressed as the RNA:DNA ratio. Typically when RNA:DNA, RNA:protein, protein:DNA ratios are correlated with recent growth, RNA:DNA ratios explain the largest part of the variance (Malloy \& Targett 1994, Hoch 1998, Melzner 2001). However, normalisation using the RNA:DNA ratio doesn't completely remove the effect of body size or developmental stage (Clemmesen 1994, Bergeron 1997, Clemmesen et al. 1997).

Higher RNA:DNA ratios were correlated with higher growth rates and characterised the feeding environment the larvae faced within a time frame of ca. $1 \mathrm{wk}$ prior to sampling (Clemmesen 1994, Bailey et al. 1995). The second most important factor influencing the RNA:DNA ratio and its predictional power of growth is the effect of temperature. A higher temperature experi- 
enced by the larvae has been shown to lead to a decrease in the RNA:DNA ratio at a given growth rate, due to the fact that higher temperatures enable higher protein turnover rates with the given numbers of ribosomes available (Goolish et al. 1984). Buckley (1984) demonstrated a positive relationship among the protein growth rates of larvae of 8 different marine fish species, their RNA:DNA ratios and the ambient water temperature, with higher temperature leading to an increase in growth rate. Most published studies have dealt with marine fish larvae; studies on freshwater fish larvae are limited in comparison (Ferguson \& Danzmann 1990, Steinhart \& Eckmann 1992, Mathers et al. 1993).

The aim of this study was to test the effect of 2 different temperatures on the growth of larval and juvenile North Sea houting, an anadromous coregonid fish near to extinction that was reared in the laboratory for $36 \mathrm{~d}$, based on measurements of standard length, dry weight, muscle DNA- and RNA concentrations as well as RNA:DNA ratios. To be able to compare the temperature effect on growth and nucleic acids, and in order to reduce the age, development, or size effects, the data were analysed in relation to degree-days experienced, meaning that larvae with the same temperature history, but not the same age, are directly compared. To reduce the effect of varied feeding densities on growth, larvae were fed constantly ad libitum on dry food with automatic feeders for $24 \mathrm{~h} \mathrm{~d}^{-1}$.

\section{MATERIALS AND METHODS}

Fish used in this experimental study were newly hatched larvae of the North Sea houting Coregonus oxyrhynchus. Eggs were stripped from wild fish caught by electrofishing in the river Treene, northern Germany, in December 1999. Fertilized eggs from 9 females and 8 males were coldbred at incubation temperatures between 0.5 and $1.5^{\circ} \mathrm{C}$. To induce hatching, eggs were transferred to unchilled springwater $\left(\sim 9^{\circ} \mathrm{C}\right)$ in the middle of March 2000. Hatching occurred $12 \mathrm{~h}$ after transfer. The experiments were carried out at 2 temperatures $\left(8.4^{\circ} \mathrm{C}, \mathrm{SD}=0.7\right.$ and $\left.17.5^{\circ} \mathrm{C}, \mathrm{SD}=0.5\right)$ in duplicate. Larvae were stocked at a density of 13 to 15 ind. $\mathrm{l}^{-1}$ in $40 \mathrm{l}$ rectangular plastic tanks after $3 \mathrm{~h}$ of temperature adjustment. The tanks were illuminated for $24 \mathrm{~h} \mathrm{~d}^{-1}$ at a light intensity from $3 \mu \mathrm{mol} \mathrm{m} \mathrm{m}^{-2} \mathrm{~s}^{-1}$ directly below the automatic feeder and $18 \mu \mathrm{mol} \mathrm{m} \mathrm{m}^{-2}$ $\mathrm{s}^{-1}$ at the brightest section, measured at the water surface (Li-Cor Li 250). Continuous light was chosen for hygiene reasons. Inducing positive phototaxis kept larvae away from the bottom of the tanks.

The larvae were fed continously ad libitum with an automatic feeder using formulated diets. Kyowa B (250 $\mu \mathrm{m}$, Kyowa Hakko Kogyo) was used as a starter food from $2 \mathrm{~d}$ posthatch. At an age of $8 \mathrm{~d}$ at $17.5^{\circ} \mathrm{C}$ and $12 \mathrm{~d}$ at $8.4^{\circ} \mathrm{C}$, formulated salmonid diets (Perla Larva 6.0, 300 to $500 \mu \mathrm{m}$ and Perla Larva 4.0, 100 to $300 \mu \mathrm{m}$ ) were added in daily increasing amounts. Visual gutcontent observations revealed that the larvae began feeding at $4 \mathrm{~d}$ posthatch. One group was deprived of food from the beginning of the trial at each temperature. The tanks were cleaned and dead larvae removed and counted daily.

Samples were taken by hand-netting after stirring the water in the tanks to evenly distribute the larvae. Larvae were stored individually in $1.5 \mathrm{ml}$ plastic vials and frozen at $-70^{\circ} \mathrm{C}$. Samples were taken at $4 \mathrm{~d}$ intervals with 20 fish per sampling from each tank at the 2 different temperatures. Due to low remaining numbers of larvae in the starved groups, the last sample at the $8.4^{\circ} \mathrm{C}$ was taken on Day 36, while it was taken on Day 16 at $17.5^{\circ} \mathrm{C}$. The surviving larvae were counted at the end of the experiment. After accounting for the sampling mortality, the cumulative mortalities were calculated on a daily basis.

After thawing the larvae, their standard lengths were measured to the nearest $0.164 \mathrm{~mm}$ below using a stereomicroscope; larvae longer than $19.68 \mathrm{~mm}$ were measured to the mm below. For biochemical analyses, pieces of white muscle tissue were cut from the area where the adipose fin would later develop. Muscle tissue was used for the analysis, because the older larvae grew to a size where the preparation of a whole-fish homogenate produced doubtful results. All measurements, dissections and homogenisation (see below) were carried out on ice. Larvae and muscle tissue samples were freeze-dried to a constant weight $(24 \mathrm{~h}$, using a Christ Alpha 1-4 freezedryer at $-51^{\circ} \mathrm{C}$ ) and were weighed to the nearest $0.0001 \mathrm{mg}$ (Sartorius microbalance SC2).

Analysis of muscle RNA- and DNA concentrations was performed by a modification of the work done by Clemmesen (1993) and Moksness et al. (2000). The freeze-dried tissue was rehydrated in Tris-SDS-buffer (Tris 0.05M, NaCl 0.01M, EDTA 0.01M, SDS 0.01\%) for $15 \mathrm{~min}$. Cells were disrupted by shaking in a cell mill with glass beads (diameter $2 \mathrm{~mm}$ and 0.17 to $0.34 \mathrm{~mm}$ ). The homogenate was centrifuged at $6000 \mathrm{rpm}$ $(3830 \times g)$ at $0^{\circ} \mathrm{C}$ for $8 \mathrm{~min}$. The supernatant was split into 2 aliquots, one for the measurement of the total nucleic acids and one for the DNA measurement. The DNA measurement was carried out by digesting the RNA with RNAse (Ribonuclease A, from bovine pancreas; SERVA 34388). The RNA fluorescence was calculated by substracting the DNA fluorescence from the fluorescence of the total nucleic acids. The nucleic acid concentrations were measured fluorometrically in a microtiter fluorescence reader (Labsystems, Fluorescan Ascent) using the fluorophor ethidium bromide. 

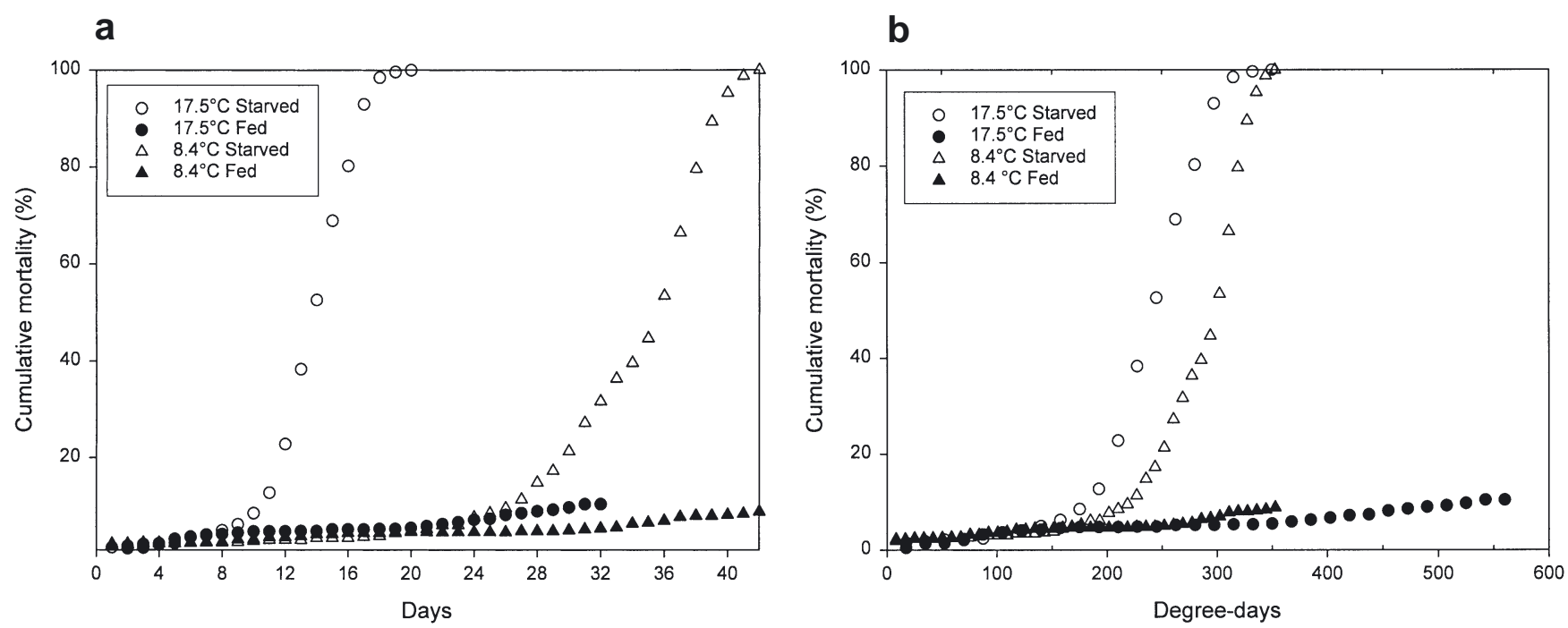

Fig. 1. Coregonus oxyrhinchus. Cumulative mortalities versus (a) larval age and (b) degree-days in laboratory reared larval North Sea houting

Muscle DNA- and RNA concentrations were calculated as $\mu \mathrm{g}$ DNA or $\mu \mathrm{g}$ RNA per mg tissue using linear regressions. For the DNA calibration, Lambda DNA (Boehringer 745782) was used, and the RNA calibration used 16S and 23S RNA from Escherichia coli (Boehringer 206938). As the analysis was based on muscle samples, the results cannot be used for calculation of whole fish body values, since different tissues or body parts can have different RNA- or DNA-tissue relationships (Houlihan et al. 1988). The KolmogorovSmirnov non-parametric test was used for statistical analysis, which was chosen because not all data were normally distributed.

For the detection of small-scale changes in distribution patterns of the parameters analysed, a nonparametric approach proposed by Pepin et al. (1999) and Evans (2000) was used. This approach examines how the probability distribution of a random variable $Y$ (e.g. cell size $=$ DNA per mg muscle) depends on some other variable $X$ (weight), without any assumptions about the form of the distributions or dependence. The goal is achieved by estimating cumulative probability distributions and by computing local influences of $X$ on $Y$, based on locally weighted estimates of the cumulative probability distribution by kernel smoothing (Pepin et al. 1999, Evans 2000). In this study, the 50th (median), 10th (lower extreme) and 90th (upper extreme) percentiles of the distribution were analysed. The use of these percentiles gives the opportunity to detect small shifts in patterns. The approach of this paper was to detect small changes in growth which are potentially lost in statistical approaches based on means. These changes are normally found at the extremes of distributions (Pepin et al. 1999, Evans 2000) and have minor influences on common statistical tests.

\section{RESULTS}

Cumulative mortalities in the fed groups were relatively low, with higher mortalities at the higher temperature (cumulative mortalities over the $32 \mathrm{~d}$ rearing period of $5.5 \%$ at $8.4^{\circ} \mathrm{C}, 10 \%$ at $17.5^{\circ} \mathrm{C}$ ). In all, 498 and 583 larvae survived until the end of the experiments at 8.4 and $17.5^{\circ} \mathrm{C}$ respectively. No mortality peaks occurred in fed fish during the experiment. The survival time of non-fed larvae differed significantly between the temperatures. While the mortalities started to increase rapidly on Day 28 and the last larvae died on Day 42 at $8.4^{\circ} \mathrm{C}$, the mortalities at $17.5^{\circ} \mathrm{C}$ increased ca. $20 \mathrm{~d}$ earlier, with the last larvae dying on Day 20 (Fig. 1a).

When the cumulative mortalities were compared to the product of temperature and age (degree-days), the development of the mortalities was rather similar. In starved groups at both temperatures, mortalities started to increase at approx. 180 degree-days, and at both temperatures the last larvae died at 350 degreedays. The mortalities in the fed groups at 350 degreedays (comparable data range) showed an inverse pattern compared to the situation after $32 \mathrm{~d}\left(9 \%\right.$ at $8.4^{\circ} \mathrm{C}$ and $5.5 \%$ at $17.5^{\circ} \mathrm{C}$ ) (Fig. $1 \mathrm{~b}$ ).

For fed fish, the samples from the corresponding tanks and sampling dates were pooled because no significant differences were found between the replicates. Comparison of larval size, dry weight, RNA- and DNA concentrations and the RNA:DNA ratio of $32 \mathrm{~d}$ old larvae showed that all parameters tested were significantly affected by temperature (Table 1).

Larvae grew faster at the higher temperature. The larvae reached a mean dry weight of $3.6 \mathrm{mg}$ (SD: 1.07, range: 1.4 to $5.6 \mathrm{mg}$ ) at $8.4^{\circ} \mathrm{C}$ compared to $31.5 \mathrm{mg}$ (SD: 
Table 1. Coregonus oxyrhinchus. Effect of temperature on fed larvae at $32 \mathrm{~d}$ posthatch (Kolmogorov-Smirnov test)

\begin{tabular}{|c|c|c|c|}
\hline & \multicolumn{2}{|c|}{ Mean } & \multirow{2}{*}{$\mathrm{p}$} \\
\hline & $8^{\circ} \mathrm{C}$ & $18^{\circ} \mathrm{C}$ & \\
\hline Dry weight (mg) & 3.66 & 31.45 & $<0.05$ \\
\hline Standard length (mm) & 17.69 & 24.87 & $<0.05$ \\
\hline RNA ( $\mu$ g mg tissue ${ }^{-1}$ ) & 8.93 & 6.24 & $<0.05$ \\
\hline DNA ( $\mu \mathrm{g}$ mg tissue ${ }^{-1}$ ) & 4.80 & 4.17 & $<0.05$ \\
\hline RNA:DNA ratio & 1.88 & 1.57 & $<0.05$ \\
\hline
\end{tabular}

21.9, range: 3.6 to $96.0 \mathrm{mg}$ ) at $17.5^{\circ} \mathrm{C}$ at the end of the experiment. This shows that a temperature increase of nearly $10^{\circ} \mathrm{C}$ led to a nearly 10 -fold increase in final dry weight (Fig. 2a). Differences in dry weight between
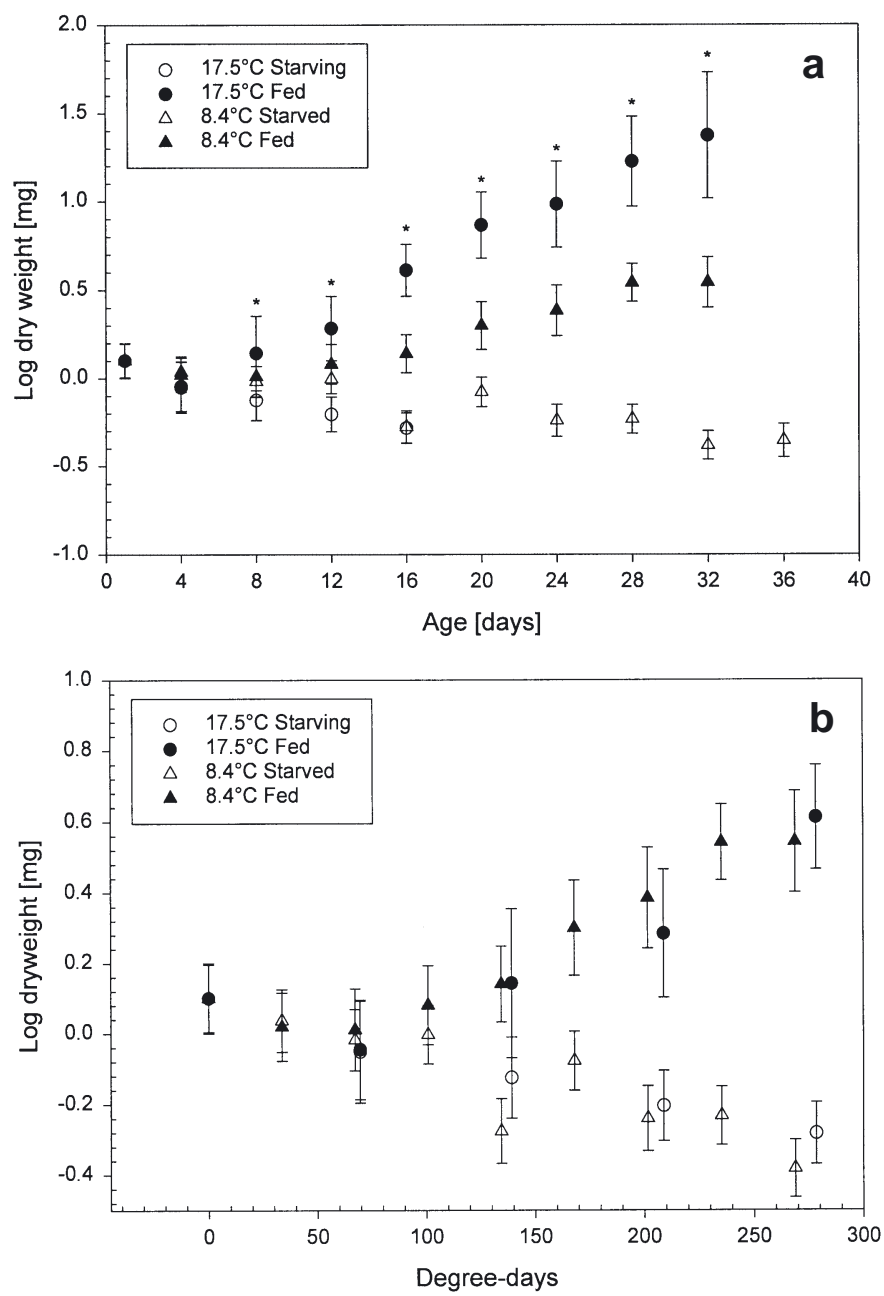

Fig. 2. Coregonus oxyrhinchus. (a) Dry-weight-age relationship in larval North Sea houting. * Represents significant differences of fed larvae between temperatures, based on Kolmogorov-Smirnov test, p > 0.05. (b) Dry-weight-degree-day relationship in larval North Sea houting. First 280 degreedays shown. Values are means $(n=40) \pm 1$ SD the 2 temperature groups were found from an age of $4 \mathrm{~d}$, with the larvae from the $8.4^{\circ} \mathrm{C}$ group having higher dry weights due to the fact that the yolk absorption was delayed in comparison to $17.5^{\circ} \mathrm{C}$. However, these differences were not significant (KolmogorovSmirnov test). The significant effect of higher temperature leading to an increase in larval dryweight was seen from Day 8 until the end of the experiment (Kolmogorov-Smirnov test, $\mathrm{p}<0.05)$. Larvae deprived of food at $8.4^{\circ} \mathrm{C}$ survived for $42 \mathrm{~d}$, decreasing their dryweight to mean values of $0.45 \mathrm{mg}$ on Day 36, whereas the starved larvae at a temperature of $17.5^{\circ} \mathrm{C}$ survived for $20 \mathrm{~d}$, reaching a mean dry weight of $0.53 \mathrm{mg}$ on Day 16 (Fig. 2a).

The temperature life-history of the larvae, expressed as the product of mean temperature and
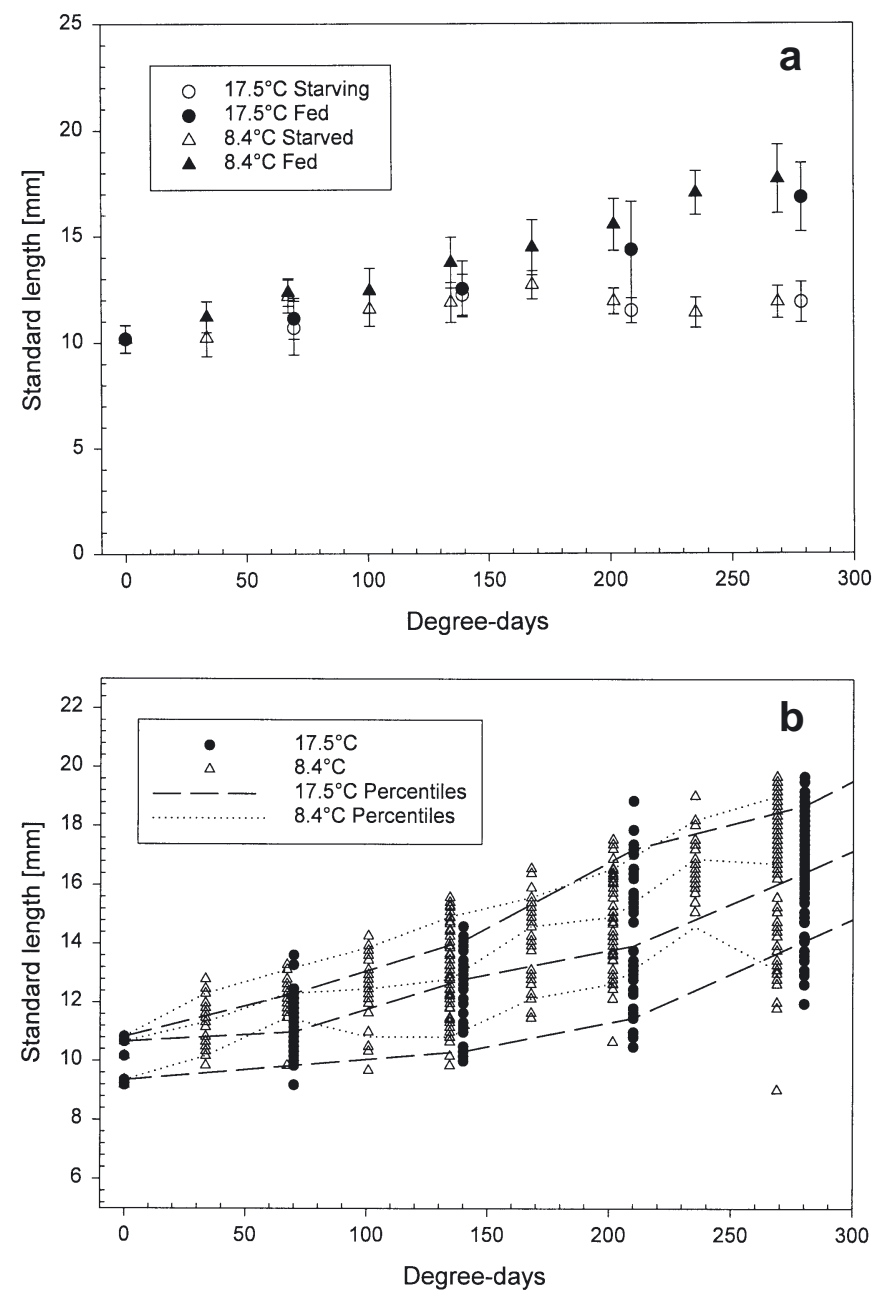

Fig. 3. Coregonus oxyrhinchus. (a) Standard-length-degree-day relationship in larval North Sea houting. First 280 degree-days shown. Values are means $(n=40) \pm 1$ SD. (b) Standard-lengthdegree-day relationship in larval North Sea houting. Dotted $\left(8.4^{\circ} \mathrm{C}\right)$ and dashed $\left(17.5^{\circ} \mathrm{C}\right)$ lines from bottom to top are 10th, 50 th, and 90th percentiles. First 280 degree-days shown 


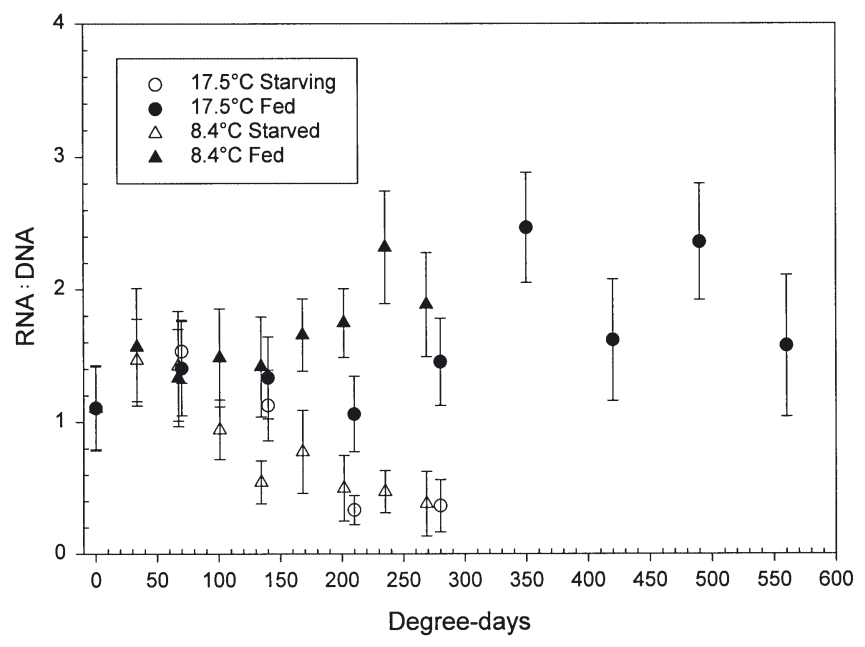

Fig. 4. Coregonus oxyrhinchus. RNA:DNA ratio development compared to degree-days in larval North Sea houting. Full data range shown. Values are means $(n=40) \pm 1 \mathrm{SD}$

Table 2. Coregonus oxyrhinchus. Effect of temperature on fed larvae at 280 degree-days (Kolmogorov-Smirnov test)

\begin{tabular}{|c|c|c|c|}
\hline & \multicolumn{2}{|c|}{ Mean } & \multirow{2}{*}{$\mathrm{p}$} \\
\hline & $8^{\circ} \mathrm{C}$ & $18^{\circ} \mathrm{C}$ & \\
\hline Dry weight (mg) & 3.66 & 4.31 & $>0.05$ \\
\hline Standard length (mm) & 17.69 & 16.83 & $>0.05$ \\
\hline RNA ( $\mu g$ mg tissue ${ }^{-1}$ ) & 8.93 & 8.52 & $>0.05$ \\
\hline DNA $\left(\mu \mathrm{g}\right.$ mg tissue $\left.{ }^{-1}\right)$ & 4.80 & 6.02 & $<0.05$ \\
\hline RNA:DNA ratio & 1.88 & 1.45 & $<0.05$ \\
\hline
\end{tabular}

Table 3. Coregonus oxyrhinchus. Effect of temperature in starved larvae on the last sampling date, 280 degree-days (Kolmogorov-Smirnov test)

\begin{tabular}{|c|c|c|c|}
\hline & \multicolumn{2}{|c|}{ Mean } & \multirow{2}{*}{$\mathrm{p}$} \\
\hline & $8^{\circ} \mathrm{C}$ & $18^{\circ} \mathrm{C}$ & \\
\hline Dry weight (mg) & 0.42 & 0.53 & $<0.05$ \\
\hline Standard length $(\mathrm{mm})$ & 11.87 & 11.87 & $>0.05$ \\
\hline RNA ( $\mu g$ mg tissue $^{-1}$ ) & 4.40 & 5.99 & $>0.05$ \\
\hline DNA ( $\mu g$ mg tissue $\left.{ }^{-1}\right)$ & 11.92 & 16.93 & $<0.05$ \\
\hline RNA:DNA ratio & 0.38 & 0.36 & $>0.05$ \\
\hline
\end{tabular}

ferences in growth of fed larvae were observed (Table 2). Fig. 3a suggests that a colder water temperature produced longer larvae at comparable temperature life-histories, while no significant differences in dry weight were observed (Table 2). In comparison, Fig. 3b shows that the differences between temperatures are created at the lower parts of the distribution by the absence of smaller larvae, visualised by the tenth percentile. Significant differences in DNA concentration and the RNA:DNA ratio were also present at 280 degree-days (Table 2).

The RNA:DNA ratio in fed fish showed a shift to higher values at $8.4^{\circ} \mathrm{C}$ starting on degree-days 170 and 280 at $17.5^{\circ} \mathrm{C}$ (Fig. 4). At $8.4^{\circ} \mathrm{C}$ the shift in the RNA:DNA ratio was induced mainly due to an increase in RNA concentration, while the DNA concentration stayed relatively constant (Figs. 5 \& 6). At $17.5^{\circ} \mathrm{C}$ this shift in the RNA:DNA ratio was induced by a decrease in DNA concentration, meaning a change in the relationship between amount of DNA to amount of cytoplasm, while the RNA concentration remained fairly constant.

Comparing the starved groups at both temperatures in the first 280 degree-days (time frame where data for both temperatures are available), significant differences at 280 degree-days occurred only in dry weight and the DNA concentration (Table 3). With 352 and 348 degree-days at 8.4 and $17.5^{\circ} \mathrm{C}$, respectively, the starvation time was similar.

A clear differentiation between growing and starved larvae based on the nucleic acid concentrations could be found at both temperatures (Table 4). While the RNA:DNA ratio in fed fish showed a slight increase, the ratio in starved larvae declined rapidly (Fig. 4). This decline is mainly caused by a sharp rise in DNA concentration, while the RNA concentration only decreased slightly (Figs. 5 \& 6). This pattern was also found in fed fish at 134 degree-days at $8.4^{\circ} \mathrm{C}$ and at 210 degree-days at $17.5^{\circ} \mathrm{C}$, where a decrease in the RNA:DNA ratio took place corresponding to a change in diet. the age of larvae (degree-days), can demonstrate the temperature dependence of growth assuming that there is a linear relation between temperature and growth. The development of the dry weights of fed and starved fish expressed in degree-days (Fig. 2b) showed a different pattern compared to the age relationship (Fig. 2a). In a comparable period of the experiment (first 280 degree-days after hatch), small but significant dif-
Table 4. Coregonus oxyrhinchus. Effect of the feeding regime between fed and staved larvae within the 2 temperatures at the last sampling date for starved larvae, 280 degree-days (Kolmogorov-Smirnov test)

\begin{tabular}{|c|c|c|c|c|c|c|}
\hline & \multicolumn{3}{|c|}{$-8^{\circ} \mathrm{C}$} & \multicolumn{2}{|c|}{$18^{\circ} \mathrm{C}$} & \multirow{3}{*}{$\mathrm{p}$} \\
\hline & \multicolumn{2}{|c|}{ Mean } & \multirow[t]{2}{*}{$\mathrm{p}$} & \multicolumn{2}{|c|}{ Mean } & \\
\hline & Fed & Starved & & Fed & Starved & \\
\hline Dry weight (mg) & 3.66 & 0.42 & $<0.05$ & 4.31 & 0.53 & $<0.05$ \\
\hline Standard length (mm) & 17.69 & 11.87 & $<0.05$ & 16.83 & 11.87 & $<0.05$ \\
\hline RNA ( $\mu g$ mg tissue ${ }^{-1}$ ) & 8.93 & 4.40 & $<0.05$ & 8.52 & 5.99 & $<0.05$ \\
\hline DNA ( $\mu \mathrm{g}$ mg tissue ${ }^{-1}$ ) & 4.80 & 11.92 & $<0.05$ & 6.02 & 16.93 & $<0.05$ \\
\hline RNA:DNA ratio & 1.88 & 0.38 & $<0.05$ & 1.45 & 0.36 & $<0.05$ \\
\hline
\end{tabular}




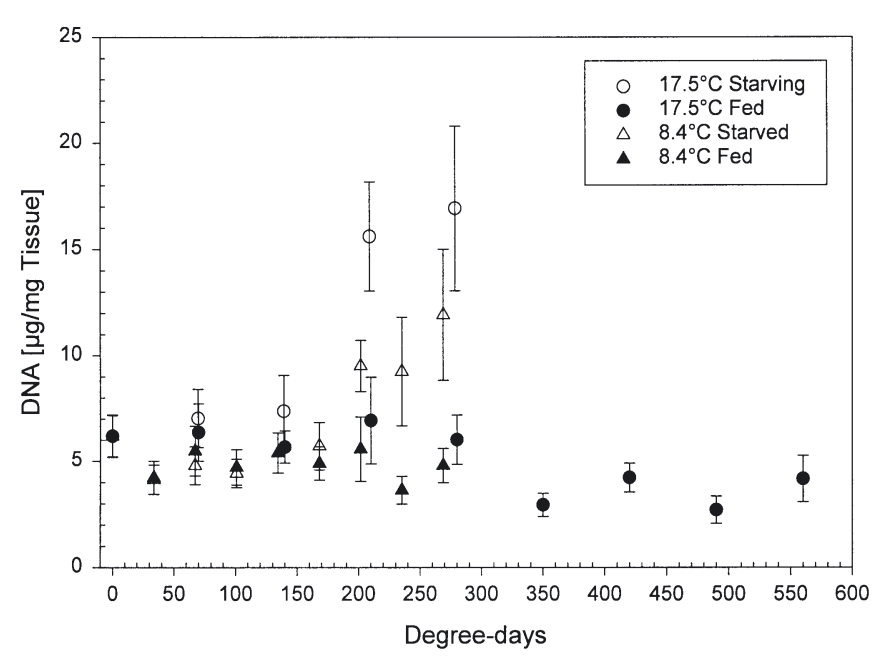

Fig. 5. Coregonus oxyrhinchus. DNA development compared to degree-days in larval North Sea houting. Full data range shown. Values are means $(n=40) \pm 1$ SD

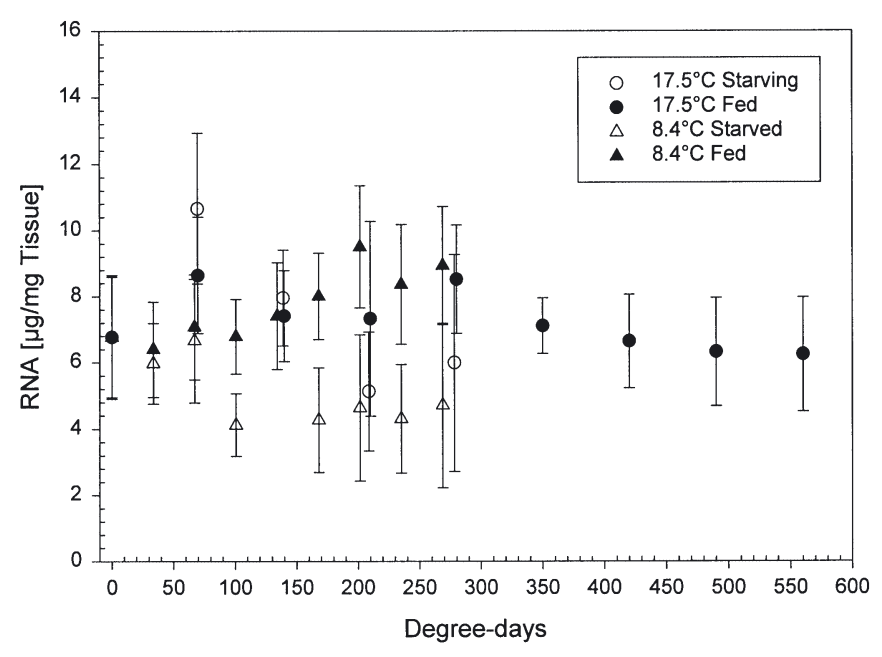

Fig. 6. Coregonus oxyrhinchus. RNA development compared to degree-days in larval North Sea houting. Full data range shown. Values are means $(\mathrm{n}=40) \pm 1 \mathrm{SD}$

In fed larvae, comparison of 10th, 50th and 90th percentiles fitted to the DNA concentration and plotted against the dry weight of the corresponding larvae showed a decrease at both temperatures with increasing weight, indicating an increase in cell size in white muscle tissue. Smaller larvae (less than $12 \mathrm{mg}$ at $17.5^{\circ} \mathrm{C}$ ) grew predominantly by increasing cell numbers (hyperplasia), indicated by the high DNA concentrations, while larger larvae grew predominantly by an increase in cell size (hypertrophy), indicated by the relatively low and constant DNA concentrations for larvae bigger than $12 \mathrm{mg}$ (Fig. 7a,b). At the colder temperature, the DNA concentrations also decreased, but no constant values were reached within the experiment.
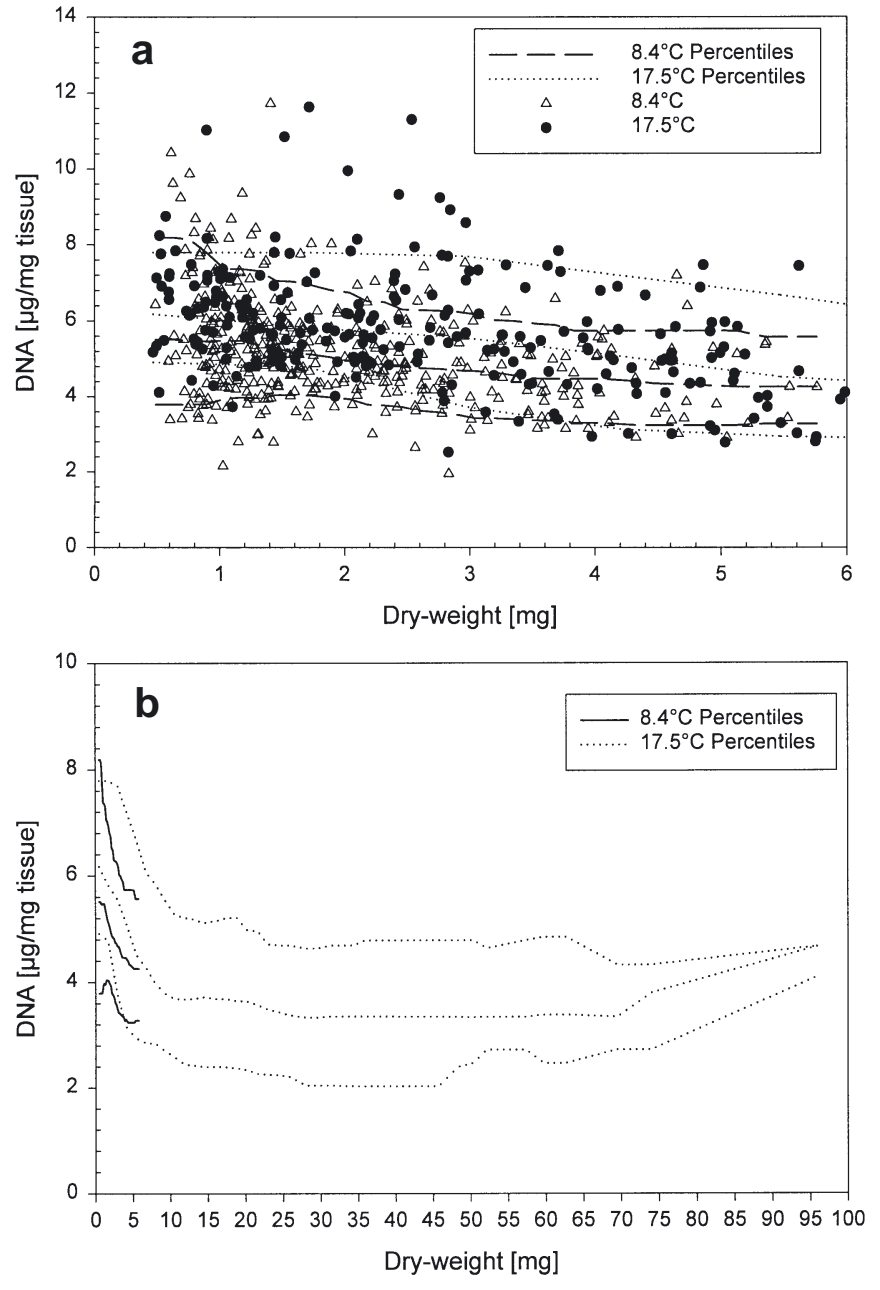

Fig. 7. Coregonus oxyrhinchus. DNA-dry-weight relationship in larval North Sea houting, with (a) data up to $6 \mathrm{mg}$ dryweight $\left(8.4^{\circ} \mathrm{C} \mathrm{n}=326,17.5^{\circ} \mathrm{C} \mathrm{n}=330\right)$ and (b) the complete data range ( 0 to $96 \mathrm{mg}$ dry-weight, showing fitted percentiles only. Dashed or solid $\left(8.4^{\circ} \mathrm{C}\right)$ and dotted $\left(17.5^{\circ} \mathrm{C}\right)$ lines from bottom to top are 10th, 50th, 90th percentiles

\section{DISCUSSION}

The aim of this study was to analyse the effect of temperature on growth of larval houting, and to study the changing patterns of nucleic acids due to different temperatures, by keeping other variables affecting growth as constant as possible. Therefore, a $24 \mathrm{~h}$ light regime and feeding ad libitum was offered at both temperatures to support optimum growth and comparable conditions.

In order to normalize the temperature effect for analysis of growth and nucleic acids, the use of the degree-day approach (age [days] $\times$ water temperature $\left.\left[{ }^{\circ} \mathrm{C}\right]\right)$ was followed, assuming that there is a linear relationship between temperature and growth. Linearity between temperature and growth can be assumed for 
the given temperature range in this study (Koskela \& Esklinen 1992).

The degree-day approach gave good results when describing the development in endogenous feeding embryos and larvae. It is more difficult in mixed and exogenous feeding larvae. In this case, development is not only controlled by age, temperature and yolkquality, but also by feeding success (Von Herbing et al. 1996). By feeding ad libitum in this study, the impact of food, and thus feeding success, can be disregarded, which is also supported by the relatively low mortalities of fed larvae in this study. Other studies have reported high mortalities in formulated-diet-fed coregonid larvae (Roesch \& Appelbaum 1985, Roesch 1989, 1992) occurring at the same time in both fed and starved larvae, which is used by the authors as an indicator for larvae refusing the formulated diets. No temporal relationship between the mortalities in fed and starved larvae was found in this study.

The data presented in this paper show a significant influence of temperature on somatic growth. At the same age, the higher temperature produced larger larvae. The data presented here are comparable with studies carried out by Roesch \& Appelbaum (1985) and Koskela \& Esklinen (1992) on Coregonus lavaretus, a near relative of the North Sea houting (Hansen et al. 1999).

The larger standard length and higher dry weight of larvae reared in colder water during the first 280 degree-days can be explained by differences in standard length and dryweight between the 2 temperatures at the lower extreme of the data distribution, meaning the absence of small fish in colder water. Taking into account that the mortalities at both temperatures were low during the experiment $\left(5 \%\right.$ at $8.4^{\circ} \mathrm{C}$, $10 \%$ at $17.5^{\circ} \mathrm{C}$ ), size-selective mortality is unlikely to explain these differences.

Nucleic acid indices can be used as an estimate of recent growth among fish showing different kinds of growth dynamics, as these indices are sensitive to both changes in length- and weight-specific growth rates (Clemmesen 1994, Buckley et al. 1999).

Somatic growth is achieved by an increased protein biosynthesis using 2 pathways to enhance protein growth: increases in RNA-content or ribosomal activity (Rosenlund et al. 1983, Miglavs \& Jobling 1989, Mathers et al. 1993). Both pathways occur in coexistence, and either one or the other pathway can dominate under specific circumstances, depending on species. Goolish et al. (1984) reported an increase of the RNA concentration with decreasing temperatures at a given growth rate in carp white muscle tissue. Buckley (1982) reported increasing protein growth rates with increasing temperature at similar RNA:DNA ratios in winter flounder Pseudopleuronectes americanus. He also noted that an increased growth rate observed at higher temperatures was not accomplished or accompanied by an increase in the RNA:DNA ratio, but rather by an increased growth rate at a given RNA:DNA ratio. These data suggest that RNA is more active at higher temperatures and that the concentration of RNA is increased at lower temperatures to compensate, in part, for the lower activity (Buckley 1982, Goolish et al. 1984, Buckley \& Bulow 1987). In this study, only a limited functional response on a quantitative level in nucleic acids to temperature was found, but a reduction in the RNA:DNA ratio in response to increasing starvation time was detected. The large differences in somatic growth combined with rather small differences in the nucleic acid concentrations between temperatures can be used as indirect evidence for a predominantly activity-driven protein biosynthesis, agreeing with Buckley's (1982) findings.

Buckley (1982, 1984), Ferguson \& Danzmann (1990) and other authors concluded that RNA:DNA ratios must be treated with caution as far as recent growth for fish from different thermal environments are concerned. Thus RNA:DNA ratios in fishes collected from warmer waters will lead to reduced estimates of somatic growth if directly compared. For the calculation of growth rates from RNA:DNA ratios resulting from different thermal environments, Buckley (1984) and Suneetha et al. (1999) provided equations for temperature corrections.

The unexpected low RNA:DNA ratios found in the fed larvae are in contrast to experiments carried out by Steinhart \& Eckmann (1992). They divided well-fed and starved whitefish larvae by their RNA:DNA ratio. Fish with a ratio lower than 2.5 were supposed to be starving, those above were in good nutritional status. In this study, most RNA:DNA ratios were lower than 2.5 in obviously well-growing fish. A clear differentiation between starving and growing larvae in this study is more likely to be seen at an RNA:DNA ratio of 0.7 . Nevertheless, a clear differentiation between fed and starved larvae was observed, with a steep decline of the RNA:DNA ratio in starved larvae. The methodology alone cannot be used to explain the low RNA:DNA ratios. High RNA:DNA ratios (RNA:DNA > 8) were measured consecutively in larval and juvenile cod using the same method in the same laboratory (Clemmesen et al. 2003). The higher ratios observed by Steinhart \& Eckmann (1992) may be caused by the different methodology used (McGurk \& Kusser 1992, Gremare \& Vétion 1994, Canino \& Caldarone 1995). Although Steinhart \& Eckmann (1992) used the same standards as in the present study, a different method for the estimation of the nucleic acids was used. They used 2 fluorophores (ethidium bromide for the determination of RNA and DNA and bisbenzimidazole for 
the detection of DNA) and several purification steps. In the present study, nucleic acid concentrations were determined by using ethidium bromide as the only fluorophor and degrading the RNA by RNAse. Additionally, muscle tissue was used for the nucleic acid analysis, in contrast to Steinhart \& Eckmann (1992), who used whole-fish homogenates, which are known to lead to other values than muscle samples (Bulow 1987). However, the RNA:DNA ratio of white muscle tissue is positively correlated to recent growth (Bulow 1987).

While the DNA content per cell stays constant in starving periods (Bulow 1987), lipids and proteins are used as an energy source and the water content of the cell increases (Love 1980). If the DNA-content is calculated per dry weight, a rise in DNA can be used as a strong indicator of poor nutritional condition. The steep decrease in the RNA:DNA ratio in starved larvae shown in this paper results from the steep increase in DNA concentration, coupled with a decrease in RNA concentration. Even the lower RNA:DNA ratios on 210 $\left(17.5^{\circ} \mathrm{C}\right)$ and 134 degree-days $\left(8.4^{\circ} \mathrm{C}\right)$ in fed fish are caused by the higher DNA concentrations which can be understood as a starving effect. In both cases, a change in food (particle size, compounds, brand) took place $5 \mathrm{~d}$ before. The larvae accepted the new diet with a delay of $1 \mathrm{~d}$ after the first application, but as the RNA:DNA ratios and the development of the dry weights indicates, larvae grew at a slower speed within a short adaptation period.

Another important temperature effect is that coldacclimated fish have smaller cells than warm acclimated fish (Ferguson \& Danzmann 1990). Hanel et al. (1996) concluded that in freshwater fish embryos, hyperplasia is more common under colder conditions, whereas under warmer water conditions hypertrophy is favoured. Hanel suggests that at low temperatures the more energetically expensive process of hyperplasia is chosen, where protein biosynthesis and nuclear division is required. At higher temperatures, hypertrophy seems to be more favourable since only protein biosynthesis is needed. The conclusions by Ferguson \& Danzmann (1990) and Hanel et al. (1996) cannot be supported by the data of this study. Cell size or a different growth pattern (hyperplasia in cold-adapted fish and hypertrophy in warm-adapted fish) would be reflected as higher or lower DNA contents per unit tissue. The DNA concentrations at both temperatures are similar in this study, with a trend towards higher DNA concentrations (indicative of hyperplasia) in the fish reared at $17.5^{\circ} \mathrm{C}$, contrary to the results by Ferguson \& Danzmann (1990).

Developmental stages and sizes of fish also affect growth patterns. Forstner et al. (1983) observed several changes in muscle development in coregonid larvae reared at $10^{\circ} \mathrm{C}$. The authors observed a thin layer of 'small diameter red fibres' (described by Johnston et al. 1975) from Day 4 on, which made up to $9 \%$ of the total muscle mass on Day 20. Increase in this muscle mass was realised by increasing cell numbers and not by increasing the diameter of the cells, so hyperplasia can be assumed to be present in this type of muscle. At $20 \mathrm{~d}$ post-hatch, the common red muscles developed and an additional increase in fibre diameter was observed, occurring faster in older fish. This increase in diameter was much higher in white- than in the red muscle types. The observed decrease in DNAconcentration with increasing size of the fish in the present study indicated a switch from a higher proportion of hyperplasia in small fish to a higher proportion of hypertrophy in larger fish, and could possibly be explained by the difference in muscle development and growth found by Forstner et al. (1983).

Acknowledgements. We would like to thank A. Hahn from the hatchery in Altmühlendorf, who provided the eggs and good practical advice during the rearing period, and 3 anonymous reviewers for comments which greatly improved the original manuscript.

\section{LITERATURE CITED}

Bailey KM, Houde ED (1989) Predation on eggs and larvae of marine fishes and the recruitment problem. Adv Mar Biol 25:1-83

Bailey KM, Canino MF, Napp JM, Spring SM, Brown AL (1995) Contrasting years of prey levels, feeding conditions and mortality of larval walleye pollock Theragra chalcogramma in the western Gulf of Alaska. Mar Ecol Prog Ser 119:11-23

Bergeron JP (1997) Nucleic acids in ichthyoplankton ecology: a review, with emphasis on recent advances for new perspectives. J Fish Biol 51:284-302

Buckley LJ (1982) Effects of temperature on growth and biochemical composition of larval winter flounder Pseudopleuronectes americanus. Mar Ecol Prog Ser 8:181-186

Buckley LJ (1984) RNA-DNA ratio: an index of larval fish growth in the sea. Relationships between RNA-DNA ratio, prey density, and growth rate in Atlantic cod (Gadus morhua) larvae. Mar Biol 80:291-298

Buckley LJ, Bulow FJ (1987) Techniques for the estimation of RNA, DNA, and protein in fish. In: Summerfelt RC, Hall GE (eds) The age and growth of fish. The Iowa State University Press, Ames, p 345-354

Buckley LJ, Lough RG (1987) Recent growth, biochemical composition, and prey field of larval haddock (Melanogrammus aeglefinus) and Atlantic cod (Gadus morhua) on Georges Bank. Can J Fish Aquat Sci 44:14-25

Buckley LJ, Calderone EM, Ong TL (1999) RNA-DNA ratio and other nucleic acid-based indicators for growth and condition of marine fishes. Hydrobiologia 401:265-277

Bulow FJ (1987) RNA-DNA ratios as indicators of growth in fish: a review. In: Summerfelt RC, Hall GE (eds) Age and growth of fish. Iowa State University Press, Ames, p 45-64

Canino MF, Caldarone EM (1995) Modification and comparison of two fluorometric techniques for determining nucleic 
acid contents of fish larvae. Fish Bull 93:158-165

Clemmesen C (1993) Improvements in the fluorimetric determination of the RNA and DNA content of individual marine fish larvae. Mar Ecol Prog Ser 100:177-183

Clemmesen C (1994) The effect of food availability, age or size on the RNA/DNA ratio of individually measured herring larvae: laboratory calibration. Mar Biol 118:377-382

Clemmesen C, Sanchez R, Wongtschowski C (1997) A regional comparison of the nutritional condition of SW Atlantic anchovy larvae, Engraulis anchoita, based on RNA/DNA ratios. Arch Fish Mar Res 45:17-43

Clemmesen C, Buhler V, Carvalho G, Case R and 10 others (2003) Variability in condition and growth of Atlantic cod larvae and juveniles reared in mesocosms: environmental and maternal effects. J Fish Biol 62:706-723

Evans GT (2000) Local estimation of probability distribution and how it depends on covariates. CSAS Research Document 200/120. Available at www.dfo-mpo.gc.ca/csas

Ferguson MM, Danzmann RG (1990) RNA/DNA ratios in white muscle as estimates of growth in rainbow trout held at different temperatures. Can J Zool 68:1494-1498

Forstner H, Hinterleitner S, Mahr K, Wieser W (1983) Towards a better definition of 'metamorphosis' in Coregonus sp.: biochemical, histological and physiological data. Can J Fish Aquat Sci 40:1224-1232

Goolish EM, Barron MG, Adelman IR (1984) Thermoacclimatory response of nucleic acid and protein content of carp muscle tissue: influence of growth rate and relationship to glycine uptake by scales. Can J Zool 62:2164-2170

Gremare A, Vetion G (1994) Comparison of several spectrofluorimetric methods for measuring RNA and DNA concentrations in the deposit-feeding bivalve Abra ovata. Comp Biochem Physiol B 107:297-308

Gronkjaer P, Clemmesen C, St.-John M (1997) Nutritional condition and vertical distribution of Baltic cod larvae. J Fish Biol 51:352-369

Hanel R, Karjalainen J, Wieser W (1996) Growth of swimming muscles and metabolic cost in larvae of whitefish at different temperatures. J Fish Biol 48:937-951

Hansen MM, Mensberg KLD, Berg S (1999) Postglacial recolonization patterns and genetic relationships among whitefish (Coregonus sp.) populations in Denmark, inferred from mitochondrial DNA and microsatellite markers. Mol Ecol 8:239-252

Hoch C (1998) Beziehungen zwischen Nukleinsäuregehalt, Wachstum und Kondition von Heringslarven. Diploma thesis, Universität Kiel

Houlihan DF, Hall SJ, Gray C, Noble BS (1988) Growth rates and protein turnover in Atlantic cod, Gadus morhua. Can J Fish Aquat Sci 45:951-964

Johnston IA, Ward PS, Goldspink G (1975) Studies on the swimming musculature of the rainbow trout. 1. Fibre types. J Fish Biol 7:451-458

Koskela J, Eskelinen U (1992) Growth of larval European whitefish (Coregonus lavaretus) at different temperatures. Pol Arch Hydrobiol 39:677-682

Leggett WC, Deblois E (1994) Recruitment in marine fishes: is it regulated by starvation and predation in the egg and larval stages? Neth J Sea Res 32:119-134

Love RM (1980) The chemical biology of fishes, Vol 2. Advances 1968-1977. Academic Press, London

Malloy KD, Targett TE (1994) The use of RNA:DNA ratios to predict growth limitation of juvenile summer flounder

Editorial responsibility: Otto Kinne (Editor), Oldendorf/Luhe, Germany
(Paralichthys dentatus) from Delaware and North Carolina nurseries. Mar Biol 118:367-375

Mathers EM, Houlihan DF, McCarthy ID, Burren LJ (1993) Rates of growth and protein synthesis correlated with nucleic acid content in fry of rainbow trout, Oncorhynchus mykiss: effects of age and temperature. J Fish Biol 43: 245-263

McGurk MD, Kusser WC (1992) Comparison of three methods of measuring RNA and DNA concentrations of individual Pacific herring, Clupea pallasi, larvae. Can J Fish Aquat Sci 49:967-974

Melzner F (2001) Determination of biochemical indices for instantaneous growth in juvenile cephalapods. Diploma thesis, Universität Kiel

Miglavs I, Jobling M (1989) Effects of feeding regime on food consumption, growth rates and tissue nucleic acids in juvenile Arctic charr, Salvelinus alpinus, with particular respect to compensatory growth. J Fish Biol 34: 947-957

Moksness E, Belchier M, Clemmesen C, Cortés D and 10 others (2000) Manual of tools for recruitment studies. PARS (Precision and accuracy of tools in recruitment studies) Final Report 2000 to the EU Commission, FAIR PL 96.1371. European Commission, Directorate General XIV Fisheries, Brussels

Pepin P, Evans GT, Shears TH (1999) Patterns of RNA/DNA ratios in larval fish and their relationship to survival in the field. ICES J Mar Sci 56:697-706

Roesch R (1989) Beginning of food intake and subsequent growth of larvae of Coregonus lavaretus L. Pol Arch Hydrobiol 36:475-484

Roesch R (1992) Food intake and growth of larvae of Coregonus lavaretus: Effect of diet and light. Pol Arch Hydrobiol 39:671-676

Roesch R, Appelbaum S (1985) Experiments on the suitability of dry food for larvae of Coregonus lavaretus L. Aquaculture 48:291-302

Rooker JR, Holt GJ (1996) Application of RNA:DNA ratios to evaluate the condition and growth of larval and juvenile red drum (Sciaenops ocellatus). Mar Freshw Res 47: 283-291

Rooker JR, Holt GJ, Holt SA (1997) Condition of larval and juvenile red drum (Sciaenops ocellatus) from estuarine nursery habitats. Mar Biol 127:387-394

Rosenlund G, Lund B, Lied E, der Decken A (1983) Properties of white trunk muscle from saithe Pollachius virens, rainbow trout Salmo gairdneri, and herring Clupea harengus: Protein synthesis in vitro, electrophoretic study of proteins. Comp Biochem Physiol B 74:389-397

Steinhart M, Eckmann R (1992) Evaluating the nutritional condition of individual whitefish (Coregonus spp.) larvae by the RNA/DNA ratio. J Fish Biol 40:791-799

Suneetha KB, Folkvord A, Johannessen A (1999) Responsiveness of selected condition measures of herring, Clupea harengus, larvae to starvation in relation to ontogeny and temperature. Environ Biol Fish 54:191-204

Suthers IM (1998) Bigger? Fatter? Or is faster growth better? Considerations on condition in larval and juvenile coralreef fish. Aust J Ecol 23:265-273

Von Herbing IH, Boutilier RG, Miyake T, Hall BK (1996) Effects of temperature on morphological landmarks critical to growth and survival in larval Atlantic cod (Gadus morhua). Mar Biol 124:593-606

Submitted: November 11, 2002; Accepted: July 1, 2003

Proofs received from author(s): August 25, 2003 